\title{
Influence of physical and biological processes on the seasonal cycle of biogenic flux in the equatorial Indian Ocean
}

\author{
P. J. Vidya ${ }^{1}$, S. Prasanna Kumar ${ }^{1}$, M. Gauns ${ }^{1}$, A. Verenkar ${ }^{1}$, D. Unger ${ }^{2}$, and V. Ramaswamy ${ }^{1}$ \\ ${ }^{1}$ National Institute of Oceanography, Dona Paula, Goa-403 004, India \\ ${ }^{2}$ Leibniz Centre for Tropical Marine Ecology GmbH, Fahrenheitstraße 6, 28359 Bremen, Germany
}

Correspondence to: S. Prasanna Kumar (prasanna@nio.org)

Received: 13 December 2012 - Published in Biogeosciences Discuss.: 18 February 2013

Revised: 4 October 2013 - Accepted: 12 October 2013 - Published: 21 November 2013

\begin{abstract}
Seasonal cycle of biogenic fluxes obtained from sediment trap at two locations $5^{\circ} 24^{\prime} \mathrm{N}, 86^{\circ} 46^{\prime} \mathrm{E}$ (southern Bay of Bengal trap; SBBT) and $3^{\circ} 34^{\prime} \mathrm{N}, 77^{\circ} 46^{\prime} \mathrm{E}$ (equatorial Indian Ocean trap; EIOT) within the equatorial Indian Ocean (EIO) were examined to understand the factors that control them. The sediment trap data at SBBT was collected for ten years from November 1987 while that at EIOT was for a one year period from January 1996. The characteristic of biogenic flux at SBBT was the strong seasonality with peak flux in August, while lack of seasonality characterised the flux at EIOT. The high chlorophyll biomass at the SBBT during the summer monsoon was supported by a combination of processes such as wind-mixing and advection, both of which supplied new nitrogen to the upper ocean. In contrast, the elevated chlorophyll at EIOT during summer monsoon was supported only by wind mixing. High cell counts of phytoplankton $(>5 \mu \mathrm{m})$ at SBBT dominated by diatoms suggest the operation of classical food web and high carbon export. On the contrary, dominance of pico-phytoplankton and one-and-a-half time higher magnitude of micro-zooplankton biomass along with 2-fold lesser meso-zooplankton at EIOT indicated the importance of microbial loop. The substantial decrease in the carbon export at EIOT indicated faster remineralization of photosynthetically produced organic matter.
\end{abstract}

\section{Introduction}

The global carbon cycle plays an important role in the Earth's climate and primary production forms an integral part of it. Phytoplankton produces half of the oxygen we breathe, draw down the atmospheric $\mathrm{CO}_{2}$, and ultimately controls the global climate system (Siegel and Franz, 2010). The biological pump in the upper ocean transfers biogenic compounds from the surface into deep waters in the form of particulate organic matter (Bishop, 1989; Longhurst, 1995; Ittekkot, 1993). Each year, the biological pump removes 7.913.1 GT C $\left(1 \mathrm{GT}=10^{15} \mathrm{~g}\right)$ of the estimated $40-60 \mathrm{GT} \mathrm{C}$ produced in the surface ocean (compiled in Boyd and Trull, 2007; Carr et al., 2006). The fraction of primary production which, is exported to waters deeper than $1500 \mathrm{~m}$ is also highly variable and ranges between $0.1-8.8 \%$ (Lutz et al., 2002).

Equatorial regions are special areas of the world ocean where intense air-sea interaction occurs. The tight coupling between the ocean and atmosphere makes the equatorial region sensitive and hence important for the climate of the Earth. The equatorial Indian Ocean (EIO) behaves uniquely compared to the other equatorial regions of the world ocean primarily due to the seasonal reversal of the winds between winter (November-February) and summer (June-September) (Hastenrath and Greishar, 1989). In response to the wind reversals surface currents also reverse in the EIO. During June to September the summer monsoon current (SMC) flows eastward in the EIO, while the winter monsoon current (WMC) flows westward during November to February (Shankar et al., 2002). Between the monsoons, during the spring (April-May) and fall (OctoberNovember) transition periods, the consistent westerly winds drive a strong narrow eastward jet known as Wyrtki jet (Wyrtki, 1973), which is equatorially-trapped (Knox, 1976; Gonella et al., 1983; Reverdin and Luyten, 1986). In addition to these zonal currents the coastal currents along the coast of India, the East Indian Coastal Current (EICC) and the West 
India Coastal Current (WICC) which also reverse their direction twice a year (Shetye and Gouveia, 1998), may play an important role in the distribution of nutrients and chlorophyll in the equatorial region.

There are two other major differences between equatorial regions of IO and other global oceans. First, equatorial upwelling does not occur in the Indian Ocean as it does in the Pacific and Atlantic where southeast trade winds blow across the equator and cause surface divergence. In the Indian Ocean, no such wind system exists in either season of the year (Schott et al., 2002). Second, the eastward equatorial undercurrent in the EIO is seen only during the winter (Knox, 1976; Leetma and Stommel, 1980; Bubnov, 1994; Reppin et al., 1999; Schott and McCreary, 2001; Masumoto et al., 2005), unlike the other oceans where it exists throughout the year (Stalcup and Metcalf, 1966; Knauss, 1960). Thus, EIO is a region of strong zonal currents (Tsai et al., 1992) and exhibits a strong semi-annual signal (Luyten and Roemmich, 1982; Reverdin, 1987; Clark and Liu, 1993). In the equatorial Pacific, physical as well as biological processes such as upwelling and remineralization by smaller organisms make the region a large source of $\mathrm{CO}_{2}$ to the atmosphere (Murray et al., 1994). This remineralization in turn leads to less export of carbon to the ocean interior in the equatorial Pacific (Beatriz et al., 2001). In contrast, strong upwelling and the dominance of faster-sinking diatoms (Bradtmiller et al., 2007) support high export of biogenic flux into the deeper ocean in the equatorial Atlantic. However, we do not have such information in the EIO.

Though our understanding of the dynamics of the EIO has increased considerably over the years, information pertaining to the biogeochemistry of this region still remains very limited due to paucity of data. The only information available in the EIO are the few studies that addressed biophysical interactions and associated carbon production in the upper ocean using in situ (Fernandes et al, 2008; Narvekar and Prasanna Kumar, 2009; Prasanna Kumar et al., 2012) as well as ecosystem model (e.g. Wiggert et al., 2006, 2009; Lévy et al., 2007; McCreary et al., 2009; Koné et al., 2009). There are no studies in the EIO that addresses the entire processes of organic carbon production in the euphotic zone, its transformation and transportation to mesopelagic zone, except that of Ramaswamy and Gaye (2006) in which they showed the dominance of carbonate producers in the EIO.

In the present study, using the biogenic flux data collected from the sediment trap mooring in the EIO, we explore (1) the role of physical and biological processes in mediating the observed variability and (2) coupling between the deep ocean biogenic flux and biological production in the upper ocean.

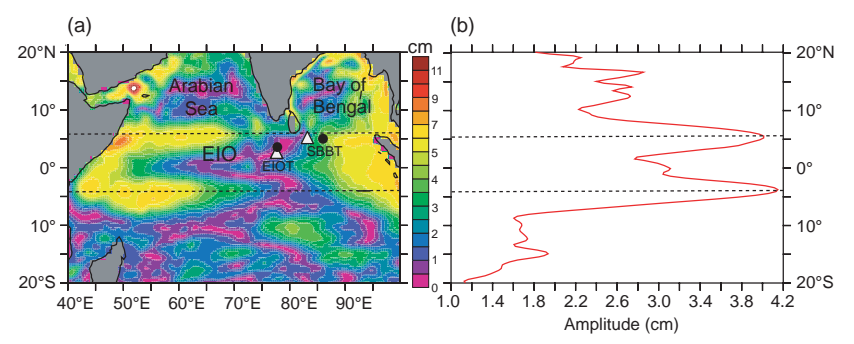

Fig. 1. (a) Spatial distribution of semi-annual amplitude of SSHA $(\mathrm{cm})$ and (b) zonal distribution of meridionally averaged semiannual amplitude of SSHA $(\mathrm{cm})$ in the Indian Ocean. Broken line defines the boundary of equatorial Indian Ocean (EIO) (see text for details). Filled black circles represent the sediment trap location SBBT and EIOT and filled white triangles represent the in-situ observation on board ORV Sagar Kanya during August 2006.

\section{Methodology and data sources}

\subsection{Study area}

In the Indian Ocean, eight sediment trap moorings were deployed during the period 1986 to 1997 under Indo-German bilateral programme to quantify the export of carbon from the ocean's surface into the ocean's interior (see Ittekkot, 1993; Rixen et al., 2009). For the present study, we have selected sediment trap moorings that are located within the EIO. In order to define the latitudinal boundary of the EIO, we used monthly mean climatology of sea surface height anomaly (SSHA) (see Sect. 2.4 for details on SSH) and subjected it to Fast Fourier Transformation (FFT) following Clark and Liu (1993). From the spatial distribution of the amplitude of the semi-annual signal (Fig. 1a) and the latitudinal distribution of zonal-averaged semi-annual amplitude (Fig. 1b) we define the region between $4.09^{\circ} \mathrm{S}$ and $5.57^{\circ} \mathrm{N}$ having the maximum amplitude as the EIO. See Clark and Liu (1993) for a similar argument to define the domain in the eastern equatorial region and Rao et al. (2010) for defining the equatorial wave guide.

Thus, we defined the region bounded by the broken line in Fig. $1 \mathrm{~b}$ as the domain of EIO. Within this domain there are two moorings (Fig. 1a). The moorings located at $5^{\circ} 24^{\prime} \mathrm{N}$, $86^{\circ} 46^{\prime} \mathrm{E}$ and at $3^{\circ} 34^{\prime} \mathrm{N}, 77^{\circ} 46^{\prime} \mathrm{E}$ are designated as southern Bay of Bengal trap (SBBT) and equatorial Indian Ocean trap (EIOT) respectively (see Rixen et al., 2009).

\subsection{In situ data}

\subsubsection{Biogenic flux data}

The biogenic flux data which include organic carbon, calcium carbonate and biogenic silica were collected by using PARAFLUX Mark VI time-series sediment traps deployed at the SBBT (Unger et al., 2003) and EIO (Ramaswamy and Gaye, 2006). The SBBT data is for a period of ten years 
from November 1987 to December 1997, while the EIOT data is for one year period from January to December 1996. The sampling intervals at both the locations varied between 9 days to 42 days. Though two traps (shallow and deep) were deployed at each location, we used only shallow trap data for the present study as our aim is to understand the processes and coupling between the biological production in the euphotic zone and the mid-depth biogenic flux. The nominal depth of the shallow trap at SBBT was $1000 \mathrm{~m}$ while that at EIOT was $912 \mathrm{~m}$. At first we converted this data into the respective calendar month for the entire period and from this the monthly mean climatology was generated to study the seasonal cycle at both the locations.

We are aware of the methodological shortcomings that are associated with flux measurements using sediment traps. Biases due to hydrodynamic flows over the trap mouth, particle transformation by bacteria and zooplankton as well as the influence of swimmers within the trap may lead to an underor over-estimation of particle fluxes by a factor of up to 2 . The calibration of particle fluxes with U-Th radionuclides has shown that fluxes at depths $<1000 \mathrm{~m}$ may be compromised because currents are stronger and zooplankton mainly migrates within this depth horizon (see Buesseler et al., 2007; Boyd and Trull, 2007). Depending on trap depth, sinking speed of particles and current speed, particles captured at one site may derive from a surface area as large as several hundreds of kilometres in diameter above the trap position. In addition to the large potential source area, the origin of particles might also vary in the course of one year. The time series thus obtained might represent export not from a defined, but rather from a variable, source region making it difficult to relate it to euphotic zone processes over the trap alone (Siegel and Deuser, 1997; Siegel et al., 1990; Waniek et al., 2005; Siegel et al., 2008).

However, sediment traps are the only tool to monitor fluxes to a certain water depth continuously and over longer time spans and the usefulness of trap data have been proven by many studies showing that the observed fluxes actually relate to surface water processes. They are consistent with the spatial variation of surface production and sediment properties (e.g. Jickells et al., 1996; Honjo et al., 1999; Waniek et al., 2005) and reveal consistent seasonal as well as interannual variation driven by surface water processes (e.g. Waniek et al., 2005; Hakke et al., 1996; Rixen et al., 2006; Holmes et al., 2002; Fischer et al., 1988; Wefer and Fischer, 1993; Voss et al., 1996).

\subsubsection{Biological mesurements}

All the biological parameters used for the present study were measured during the cruise of ORV Sagar Kanya SK-227 during August 2006. Water samples from eight depths $(0 \mathrm{~m}$, $10 \mathrm{~m}, 20 \mathrm{~m}$ and thereafter every $20 \mathrm{~m}$ interval up to a depth of $120 \mathrm{~m}$ ) were collected and analysed for measurements of various biological parameters (see below). The data from sta- tions $5^{\circ} \mathrm{N}$ and $83^{\circ} \mathrm{E}$ and $2.5^{\circ} \mathrm{N}$ and $77^{\circ} \mathrm{E}$ in the vicinity of SBBT and EIOT respectively were used for all the parameters except for the meso-zooplankton in the vicinity of SBBT which was from $2.5^{\circ} \mathrm{N}$ and $83^{\circ} \mathrm{E}$.

\section{Chlorophyll $a$ (Fluorometric)}

For estimation of total phytoplankton biomass $(\mathrm{Chl} a), 1 \mathrm{~L}$ (litre) of water was filtered through the Whatman GF/F filter paper ( $47 \mathrm{~mm}$ diameter, $0.7 \mu \mathrm{m}$ pore size) under low vacuum pressure. The pigments were extracted in $10 \mathrm{~mL}$ of $90 \%$ acetone in the dark for $24 \mathrm{~h}$ in the refrigerator. Fluorescence was measured before and after acidification with two drops of 1.2 $\mathrm{N} \mathrm{HCl}$ following the JGOFS protocol (UNESCO, 1994).

\section{Size fractionated chlorophyll $a$}

Size fractionation of phytoplankton biomass was measured from selective depth (surface, chlorophyll maximum and $120 \mathrm{~m}$ depth) with the help of gravity filtration by serially passing water sample (5 L) through 200, 60, 20 and $10 \mu \mathrm{m}$ meshes. Finally, the filtrate was passed through $0.7 \mu \mathrm{m} \mathrm{GF/F}$ filters by applying very low vacuum. Particulate material retained on all of these filters was then analysed following a similar protocol as in the case of $\mathrm{Chl} a$. The percentage biomass was calculated for different fractions.

\section{Primary production (PP)}

Water samples from eight depths were transferred to four $300 \mathrm{~mL}$ capacity Nalgene Polycarbonate bottles (3 light and 1 dark). ${ }^{14} \mathrm{C}$ was added $(5 \mu \mathrm{Ci} ; 185 \mathrm{kBq})$ to each bottle, and these bottles were incubated in situ at the respective depths from dawn to dusk (12 h). Incorporation of $\mathrm{NaH}^{14} \mathrm{CO}_{3}$ by phytoplankton was determined following the JGOFS Protocols (UNESCO, 1994). All samples were analysed on a Packard 2500 TR (USA, Packard) scintillation counter.

\section{Phytoplankton cell number}

For qualitative and quantitative analysis of phytoplankton (size $>5 \mu \mathrm{m}$ ), $250 \mathrm{~mL}$ of water samples were collected from the euphotic zone (8 depths; $0-120 \mathrm{~m}$ ) fixed in acid Lugol's iodine $(1 \% \mathrm{w} / \mathrm{v})$ and preserved in $3 \%$ formalin solution. The samples were stored in dark at low temperature until enumeration within a period of one month after collection. A settling and siphoning procedure was followed to obtain $50 \mathrm{~mL}$ concentrate. One $\mathrm{mL}$ in duplicates of this concentrate was then mounted on a Sedgwick Rafter counting chamber and examined through Olympus inverted microscope (magnification 100-200 $\times$ ). Generic and species identification was done according to various standard taxonomic keys (Subrahmanyan, 1946; Tomas, 1997; Lebour, 1978). 


\section{Meso-zooplankton}

Samples were collected at mid-night using Multiple Plankton Closing Net (Hydro-Bios; mouth area $0.25 \mathrm{~m}^{2}$; mesh size $200 \mu \mathrm{m}$ ) equipped with a pre-calibrated flowmeter. Five depths were sampled at each station: $1000-500 \mathrm{~m}, 500$ $300 \mathrm{~m}, 300$-base of thermocline (BT), BT-top of thermocline (TT) and TT-surface (mixed layer). Samples are preserved in $5 \%$ buffered formalin solution. The biomass of mesozooplankton was determined by the displacement volume method, wherein concentrated samples were moped on absorbent paper and then displacement volume was measured using a graduated cylinder (see Madhupratap et al., 2001). Depending on the size of the sample aliquots of 5-25\% were examined for microscopic identification and enumeration to the generic/species level using a stereozoom microscope.

\section{Micro-zooplankton}

For qualitative and quantitative analysis of microzooplankton, water samples were obtained from the same eight depths mentioned above for phytoplankton. A known volume $(5 \mathrm{~L})$ of water sample pre-filtered through $200 \mu \mathrm{m}$ net was slowly passed through a $47 \mathrm{~mm}$ diameter $20 \mu \mathrm{m}$ net. The filtration was done carefully and slowly to avoid bursting of delicate forms due to pressure exerted while filtering. The filtered micro-zooplankton was then transferred to $100 \mathrm{~mL}$ GF/F filtered sea water and preserved with $1 \%$ Acid Lugol's solution (with $2 \mathrm{mg} \mathrm{L}^{-1}$ of strontium sulphate) and $1 \%$ EM Hexamine buffered formaldehyde. Samples were refrigerated in dark until analysed later in the laboratory.

\subsubsection{Hydrographic data}

Monthly mean temperature and salinity data with resolution $1^{\circ} \times 1^{\circ}$ for the period 1987 January to 1997 December were obtained from the operational ocean reanalysis system (ORA-S3; Balmaseda et al., 2008) at European Centre for Medium-Range Weather Forecasts (ECMWF; http: //apdrc.soest.hawaii.edu/datadoc/ecmwf_oras3.php). Using the above data density was computed and the mixed layer depth (MLD) was determined following $0.2 \mathrm{~kg} \mathrm{~m}^{-3}$ density criteria. The water column nitrate and silicate data for the month of August was taken from the Indian Oceanographic Data Centre (IODC) (www.nio.org).

\subsection{Reanalysis data}

The monthly surface current data was taken from Ocean Surface Current Analysis-Real time (OSCAR) (http://www. oscar.noaa.gov/) during January 1993 to December 2010, which is a real time reanalysis of currents averaged over the top $15 \mathrm{~m}$ with spatial resolution of $1^{\circ} \times 1^{\circ}$ (Bonjean et al., 2002). From these data the monthly mean climatology was computed. The zonal and meridional wind stress having a spatial resolution $1^{\circ} \times 1^{\circ}$, for the period 1970 January to 2009 December have been taken from the operational ocean reanalysis system (ORA-S3) (Balmaseda et al., 2008) at European Centre for Medium-Range Weather Forecasts (ECMWF; http://apdrc.soest.hawaii.edu/datadoc/ ecmwf_oras3.php). Using this data zonal $(u)$ and meridional wind $(v)$ speeds, and Ekman pumping velocity (Gill, 1982) were computed.

\subsection{Remote-sensing data}

In addition to the in situ data we also used remotely sensed satellite data. The monthly mean data on the chlorophyll $a$ pigment concentrations and photosynthetically active radiation (PAR) were obtained from (http://oceandata.sci.gsfc.nasa.gov/SeaWiFS/Mapped/ Monthly/chlor/) Sea-viewing Wide Field-of-view Sensor (SeaWiFS) having a spatial resolution of $9 \mathrm{~km}$ for the period September 1997 to December 2010. Monthly mean sea surface height anomaly (SSHA) with spatial resolution $0.33^{\circ} \times 0.33^{\circ}$ for the period 1993 to 2010 was obtained from AVISO (www.aviso.oceanobs.com). Monthly mean sea surface temperature $(\mathrm{SST})$ with resolution $1^{\circ} \times 1^{\circ}$ was taken from HadSST1.1 (http://www.metoffice.gov.uk/ hadobs/hadisst/data/) period January 1970 to December 2009 (Rayner et al., 2003).

\subsection{Limitations of the datasets used and its implications}

It is to be noted that the monthly mean climatology of different parameters in the present study is built from different time periods depending on the availability of a particular dataset. For example, as remotely sensed data on SSHA and reanalysis data of surface currents (OSCAR) coinciding with trap data during the period 1987-1992 is not available, their climatology was prepared using data during the periods 1993-2010. Similarly, for chlorophyll pigment concentration, data is available only after 1997 August and hence the climatology was prepared during the period 1997-2010. Since the only in situ data available for the summer monsoon at EIOT and SBBT was during August 2006, we were left with no choice though this time period did not overlap with the trap data in either location. Though the above-mentioned variations in the data duration and may contribute to some uncertainties, it is difficult to quantify them.

\section{Results}

The biogenic flux data used for the present study at SBBT is a monthly mean climatology that has been computed by taking the mean during the period 1987 to 1997 . However, at EIOT we have only one year data from January to December of 1996. The obvious question is: will this be a representative flux data of EIOT? To explore whether 1996 is a normal 


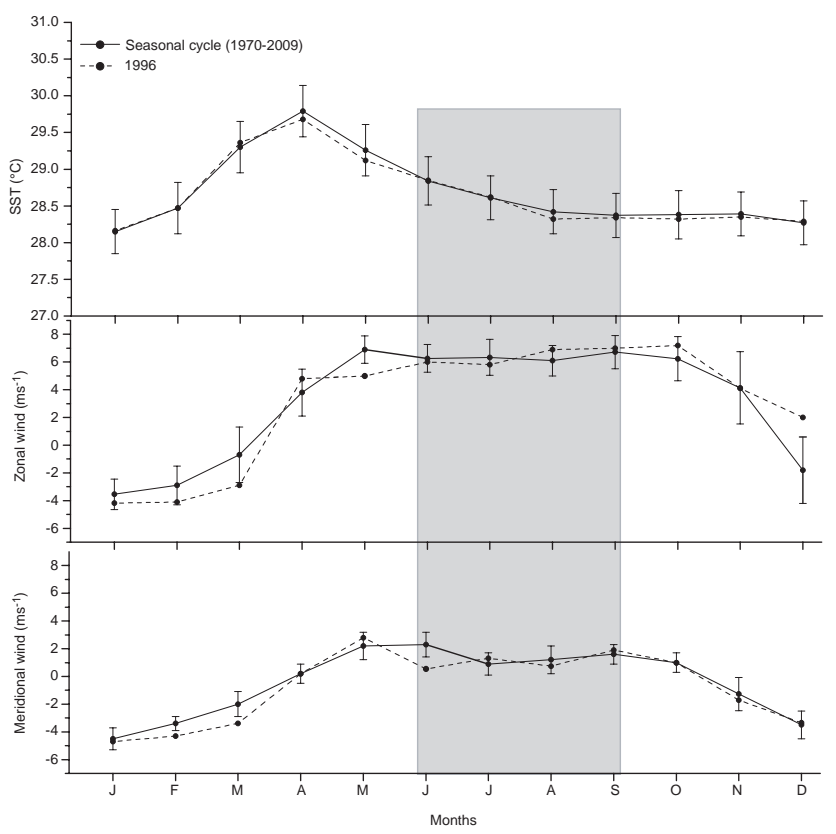

Fig. 2. Climatological monthly mean during the period 1970-2009 (thick line), and monthly mean of 1996 (dotted line) of SST (upper panel), zonal wind (middle panel) and meridional wind (bottom panel). Shading represents the summer monsoon period (JuneSeptember) and vertical lines are one standard deviation.

year we compared the oceanic (SST), as well as the atmospheric (zonal and meridional components of the wind) parameters at EIOT with that of the climatology and presented it in Fig. 2 along with SD (standard deviation). The period from June to September is shaded in the figure as the focus is on the elevated biogenic flux at SBBT with that of EIOT during this period (see the following section). It is evident from the Fig. 2 that 1996 is well within 1SD of the climatology for all the three parameters considered. This gives us the confidence to consider the flux at EIOT during 1996 as representative.

\subsection{Biogenic flux}

The seasonal cycle of biogenic flux at SBBT showed strong seasonality for the year 1996 as well as in climatology (Fig. 3a). Since the monthly mean biogenic flux during 1996 as well as climatology followed a similar pattern of seasonal variability, though with varying magnitudes, we limit our discussions to climatology. At SBBT, the average biogenic flux showed an increasing trend from June to August and attained the maximum value of $160.9 \mathrm{mg} \mathrm{m}^{-2} \mathrm{~d}^{-1}$ in August. In contrast, no distinct seasonality could be deciphered at EIOT. In general, the biogenic flux at EIOT was lower than that at SBBT. During summer monsoon (June-September) the average biogenic flux at SBBT $\left(116.1 \pm 68.1 \mathrm{mg} \mathrm{m}^{-2} \mathrm{~d}^{-1}\right)$ was about two-and-half times higher than that at EIOT $\left(42.9 \pm 18.2 \mathrm{mg} \mathrm{m}^{-2} \mathrm{~d}^{-1}\right)$. Consistent with the biogenic flux,
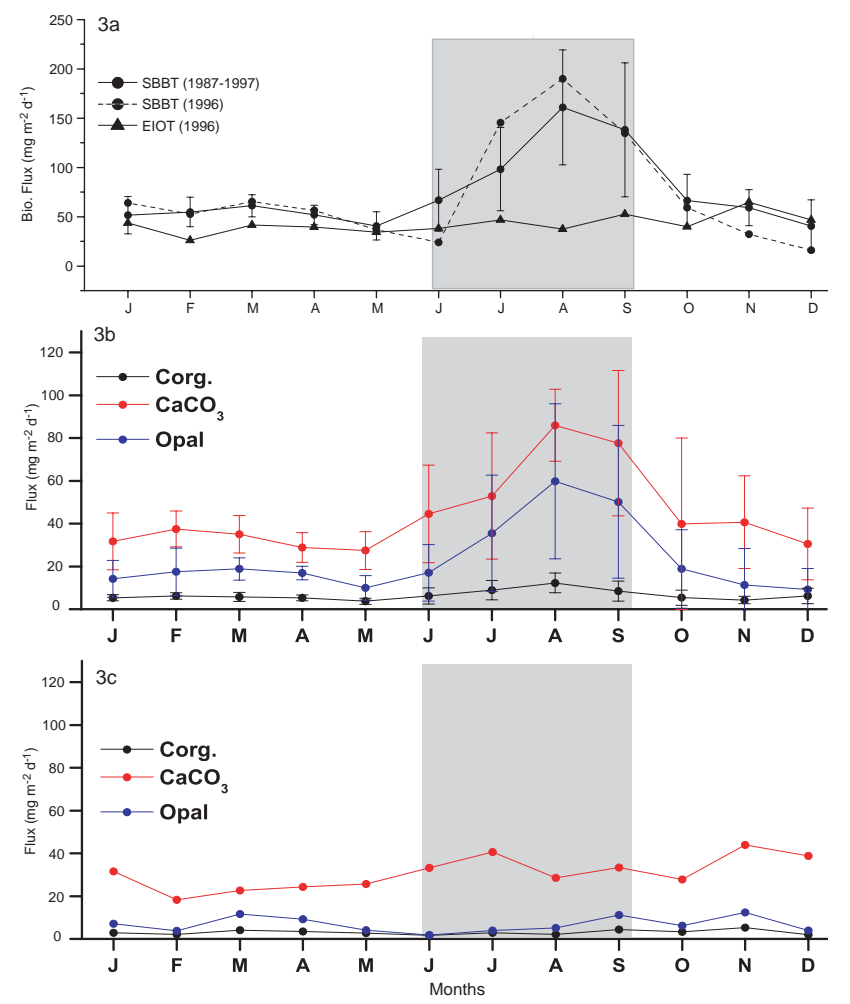

Fig. 3. Monthly mean climatology (1987-1997) of biogenic flux $\left(\mathrm{mg} \mathrm{m}^{-2} \mathrm{~d}^{-1}\right)$ at SBBT (solid line with filled circle) and monthly mean biogenic flux for the year 1996 at SBBT (broken line with filled circles) and EIOT (filled triangle). (b) and (c) represent component fluxes (red line-calcium carbonate; blue line-Opal; black line-organic carbon) at SBBT and EIOT respectively. Shading represents the summer monsoon period (June-September) and vertical lines are one standard deviation.

all the 3 component fluxes (calcium carbonate, biogenic silica and organic carbon) at SBBT also showed strong seasonality during summer monsoon (Fig. 3b), but no such seasonality was observed at EIOT (Fig. 3c). Thus, the enhancement of carbonate and silicate fluxes at SBBT indicated that phytoplankton community was dominated by coccolithophores and diatoms, while no such enhancement was seen at EIOT.

The strong seasonality of biogenic flux at SBBT and the lack of seasonality with very low flux at EIOT are intriguing, considering the fact that both the traps were located within the equatorial region (see Fig. 1a) and hence expected to experience similar atmospheric forcing. Since it has been shown that the biogenic flux to the deeper ocean is to a large extent determined by the phytoplankton production in the euphotic zone (Honjo, 1982; Betzer et al., 1984; Waniek et al., 2005; Helmke et al., 2010; Lutz et al., 2010), as a first step we compared satellite derived chlorophyll concentrations to unravel the discrepancy between fluxes at both sites. 


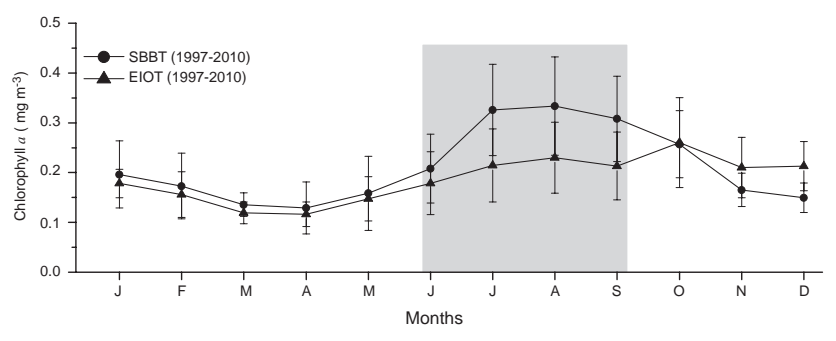

Fig. 4. Monthly mean climatology (1997-2010) of satellite derived chlorophyll pigment concentration at SBBT (filled circle) and EIOT (filled triangle). Shading represents the summer monsoon period (June-September) and vertical lines are one standard deviation.

\subsection{Satellite derived chlorophyll}

In order to understand the relation between phytoplankton and biogenic flux at deeper ocean, we calculated the climatological monthly mean remotely sensed chlorophyll pigment concentration averaged within $1^{\circ} \times 1^{\circ}$ grid centered at SBBT and EIOT respectively. It is pertinent to note that remotely sensed chlorophyll data reveals only the surface layer concentrations and will not be able to detect the presence of subsurface chlorophyll maxima (SCM). The chlorophyll pigment concentrations, though in general low, showed distinct seasonal cycle at both SBBT and EIOT (Fig. 4). Consistent with the biogenic flux at SBBT the peak chlorophyll concentration occurred in August. The chlorophyll concentrations during January to April were low $\left(0.1 \mathrm{mg} \mathrm{m}^{3}\right)$ at both SBBT and EIOT and showed an increase from May attaining the maximum value of 0.3 and $0.2 \mathrm{mg} \mathrm{m}^{-3}$ respectively. Again, unlike the biogenic flux the chlorophyll during summer monsoon at SBBT $\left(0.3 \pm 0.08 \mathrm{mg} \mathrm{m}^{-3}\right)$ and EIOT $\left(0.2 \pm 0.06 \mathrm{mg} \mathrm{m}^{-3}\right)$ did not show large differences. From the close correspondence between the time variations of chlorophyll with that of biogenic flux at SBBT it would seem that they are closely coupled. However, at EIOT the seasonality of chlorophyll and lack of seasonality of biogenic flux would need an explanation. Before attempting to address this, we explored the reason for (1) the observed seasonality in chlorophyll at both SBBT and EIOT and (2) lower chlorophyll at EIOT compared to SBBT during summer monsoon.

\subsection{Photosynthetically active radiation (PAR)}

Light, apart from nutrients, being one of the limiting factors for the growth of phytoplankton, we analysed the PAR at both the locations. PAR showed a bimodal distribution at both SBBT (standard deviation $3.2 \mathrm{E} \mathrm{m}^{2} \mathrm{~d}^{-1}$ ) and EIOT (standard deviation $3.1 \mathrm{E} \mathrm{m}^{2} \mathrm{~d}^{-1}$ ) with a primary peak in March and a secondary peak in August (Fig. 5). Though PAR was high during summer at SBBT $\left(45.7 \mathrm{E} \mathrm{m}^{2} \mathrm{~d}^{-1}\right)$ compared to EIOT $\left(43.8 \mathrm{E} \mathrm{m}^{2} \mathrm{~d}^{-1}\right)$ the difference was less than the estimated bias (2.2 $\mathrm{E} \mathrm{m}^{2} \mathrm{~d}^{-1}$; Frouin and Murakami, 2007). From the above it is evident that the marginal difference in

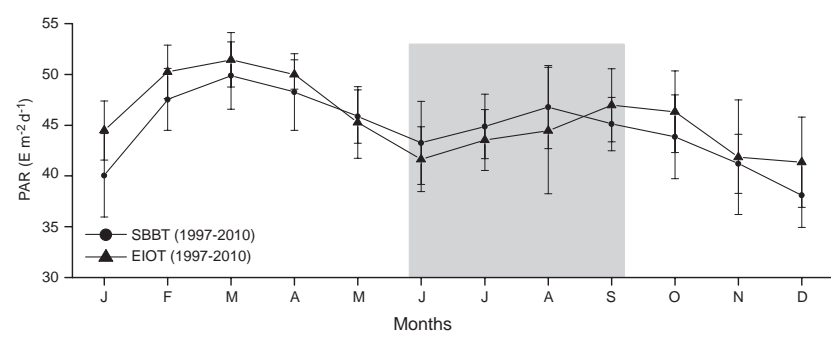

Fig. 5. Monthly mean climatology (1997-2010) of photosynthetically active radiation (PAR) at SBBT (filled circle) and EIOT (filled triangle). Shading represents the summer monsoon period (JuneSeptember) and vertical lines are one standard deviation.

PAR between SBBT and EIOT cannot account for the observed variability in the chlorophyll. The obvious reason for the variability in chlorophyll between SBBT and EIOT must be the difference in the availability of nutrients at these locations which in turn would depend upon the processes that make this nutrient available to the upper ocean.

The processes that could supply sub-surface nutrients to the upper ocean are the wind-mixing, Ekman-pumping, and advection which we examine in the following sections.

\subsection{Wind speed and static stability}

The average wind speed during summer monsoon was higher in SBBT $\left(9 \pm 0.9 \mathrm{~m} \mathrm{~s}^{-1}\right)$ than in EIOT $\left(6 \pm 1.0 \mathrm{~m} \mathrm{~s}^{-1}\right)$ (Fig. 6). The higher winds would generally result in greater wind-mixing and the extent of this mixing depends on the stability of the water column. The static stability parameter $[E]$ of the upper $200 \mathrm{~m}$ water column was calculated following Pond and Pickard (1983) and is given by

$E \approx-\frac{1}{\rho} \frac{\partial \rho}{\partial z}$

where " $\rho$ " is in situ density and $z$ is the depth taken as negative. The static stability of the water column is analogous to potential energy, which is due to the virtue of its position. A positive value of " $E$ " indicates that the water column is stable. If a parcel of water is displaced when the water column is stable, then the parcel will tend to return to its original position. On the other hand, if $E$ is negative the water column is unstable and a displaced parcel of water will continue its displacement. When $E$ is zero, the water column is neutrally stable. During August, static stability parameter at EIOT and SBBT showed similar positive values in the upper $40 \mathrm{~m}$ (Fig. 7) indicating a stable and stratified water column at both locations. Below this depth, " $E$ " showed an increase up to $100 \mathrm{~m}$ followed by a decrease below it. An examination of mixed layer depth (MLD) showed that during August MLD at SBBT was only $9 \mathrm{~m}$ deeper than that at EIOT (Fig. 8). Since the stability of the water column in the upper $40 \mathrm{~m}$ was similar at EIOT and SBBT, an increase in the magnitude of the wind at SBBT during summer monsoon did 


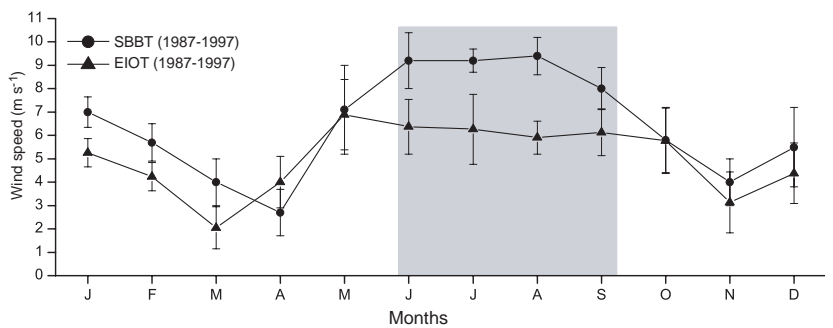

Fig. 6. Monthly mean climatology (1987-1997) of ECMWF wind speed $\left(\mathrm{m} \mathrm{s}^{-1}\right)$ at SBBT (filled circle) and EIOT (filled triangle). Shading represents the summer monsoon period (June-September) and vertical lines are one standard deviation.

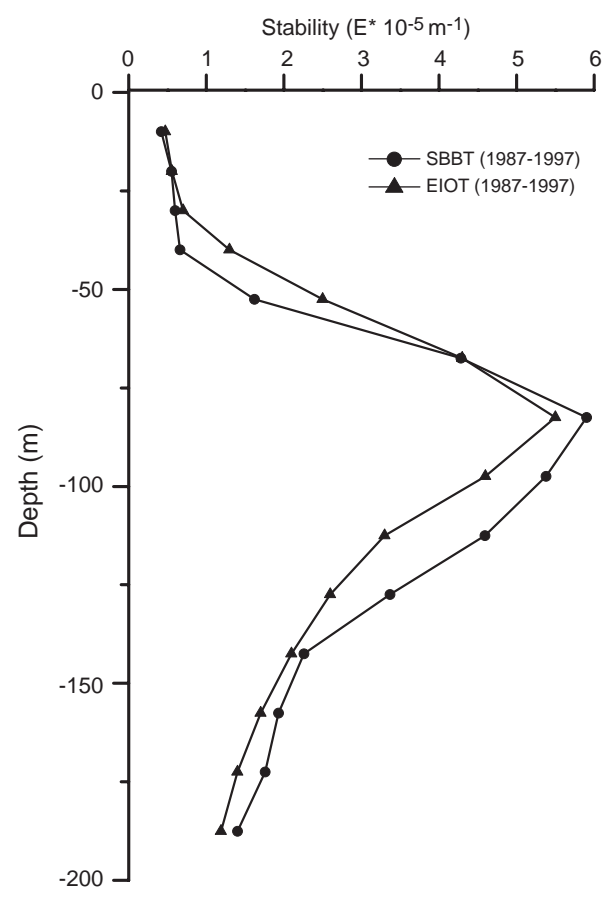

Fig. 7. Monthly mean climatology (1987-1997) of static stability of the water column $\left(\mathrm{m}^{-1}\right)$ at SBBT (filled circle) and EIOT (filled triangle) (see text for details) during August.

not lead to an increase in the MLD compared to EIOT. Thus, though the wind-mixing would have contributed to a general enhancement of chlorophyll in both locations, it could not explain the enhancement of chlorophyll at SBBT over EIOT.

\subsection{Ekman-pumping}

To explore the role of Ekman-pumping in bringing about the observed changes in the chlorophyll the spatial distribution of monthly mean Ekman-pumping velocity, computed from the ECMWF reanalysis wind, were superimposed on to the chlorophyll $a$ pigment concentrations for analysis for all the months from January to December (Fig. 9). The positive (negative) Ekman pumping velocity indicated the divergence (convergence) and upwelling (downwelling). Dur-

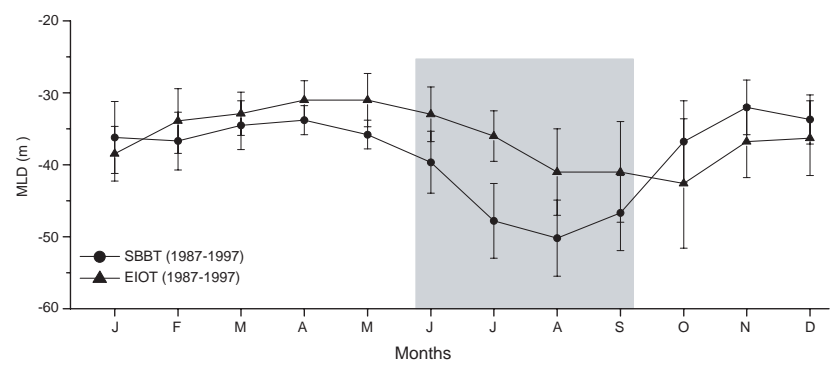

Fig. 8. Monthly mean climatology (1987-1997) of mixed layer depth (MLD), at SBBT (filled circle) and EIOT (filled triangle). Shading represents the summer monsoon period (June-September) and vertical lines are one standard deviation.

ing March-April the Ekman-pumping velocity in the vicinity of both SBBT and EIOT were zero with a chlorophyll value of $0.1 \mathrm{mg} \mathrm{m}^{-3}$ indicating oligotrophic regime. From June to September the Ekman-pumping velocity at SBBT and EIOT was negative indicating downwelling process. Hence, we infer that the enhanced chlorophyll in SBBT as well as EIOT during summer monsoon was not due to local Ekman-pumping at these locations. However, a region of positive Ekman-pumping velocity with chlorophyll in excess of $0.5 \mathrm{mg} \mathrm{m}^{-3}$ was noticed in the southern part of Sri Lanka.

\subsection{Horizontal advection}

To understand the role of horizontal advection, we analysed the spatial distribution of monthly mean climatology of chlorophyll pigment concentration overlaid with currents derived from OSCAR (Fig. 10). During summer monsoon (June-September) two strong currents were evident from the OSCAR data, the southward flowing west India coastal current (WICC) along the west coast of India (Shetye and Gouveia, 1998), and the eastward flowing southwest monsoon current (SMC) to the south. The strong SMC is capable of transporting chlorophyll and upwelled nutrients from the region south of Sri Lanka to further eastward into the trap location at SBBT (Fig. 10). Thus, at SBBT combination of windmixing and horizontal advection contributed to the observed high chlorophyll during summer monsoon, while at EIOT wind-mixing led to the moderate enhancement of chlorophyll (Fig. 4).

\subsection{Nitrate and silicate profile}

The vertical distribution of nitrate and silicate in the upper $120 \mathrm{~m}$ of the water column at SBBT and EIOT during August showed that surface water at SBBT had excess of nitrate $(0.3 \mu \mathrm{M}$; Fig. $11 \mathrm{a})$ and silicate $(4.1 \mu \mathrm{M}$; Fig. $11 \mathrm{~b})$. In contrast, at EIOT the nitrate value near surface $(3 \mathrm{~m})$ was $0.1 \mu \mathrm{M}$ and silicate was $1.7 \mu \mathrm{M}$. At $40 \mathrm{~m}$ SBBT had a nitrate concentration of $1.9 \mu \mathrm{M}$ as against $0.9 \mu \mathrm{M}$ in EIOT. Similarly, at $40 \mathrm{~m}$ depth silicate concentration at SBBT was $3.7 \mu \mathrm{M}$ as against 

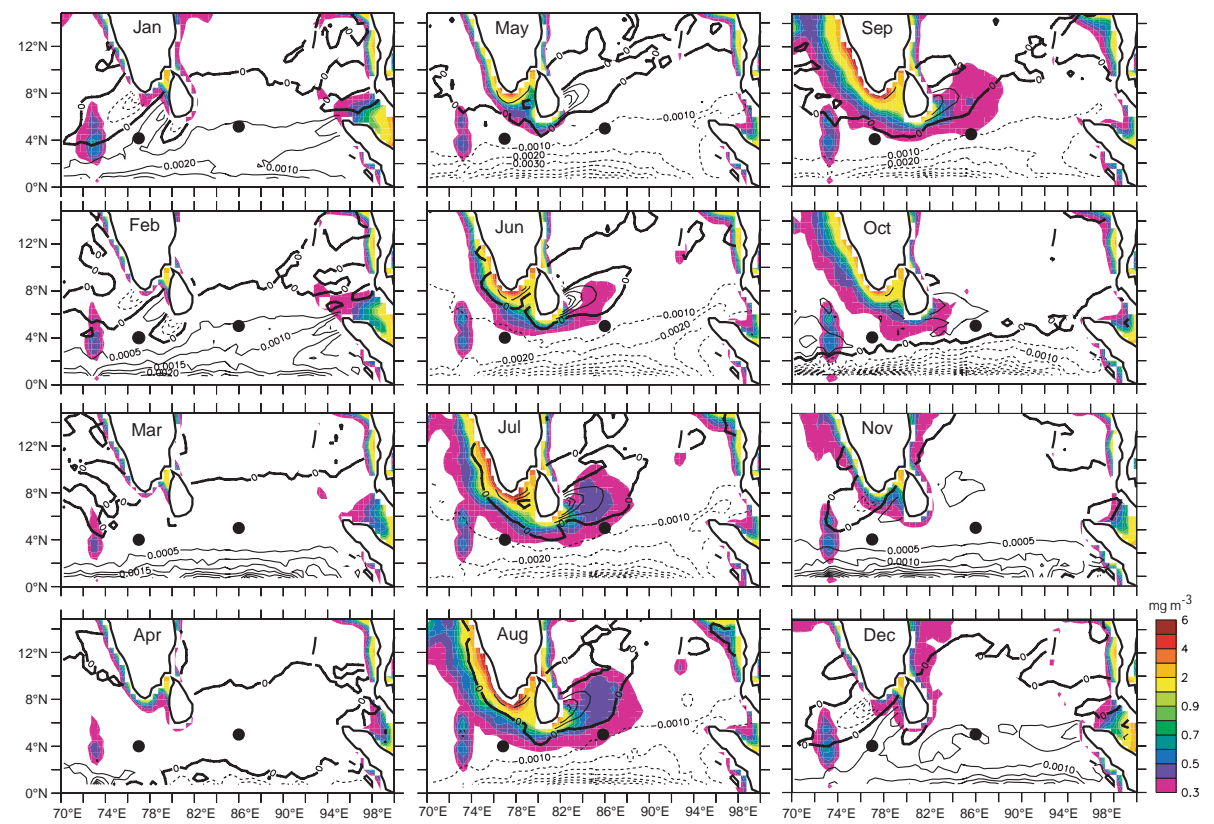

Fig. 9. Spatial distribution of monthly mean climatology (1997-2010) of the chlorophyll $\geq 0.3 \mathrm{mg} \mathrm{m}^{-3}$ (shading) overlaid with Ekmanpumping velocity (contour lines) for January to December. Solid (dashed) lines are for positive (negative) values and thick solid line is for zero Ekman-pumping velocity. Filled circles denote the location of SBBT and EIOT.

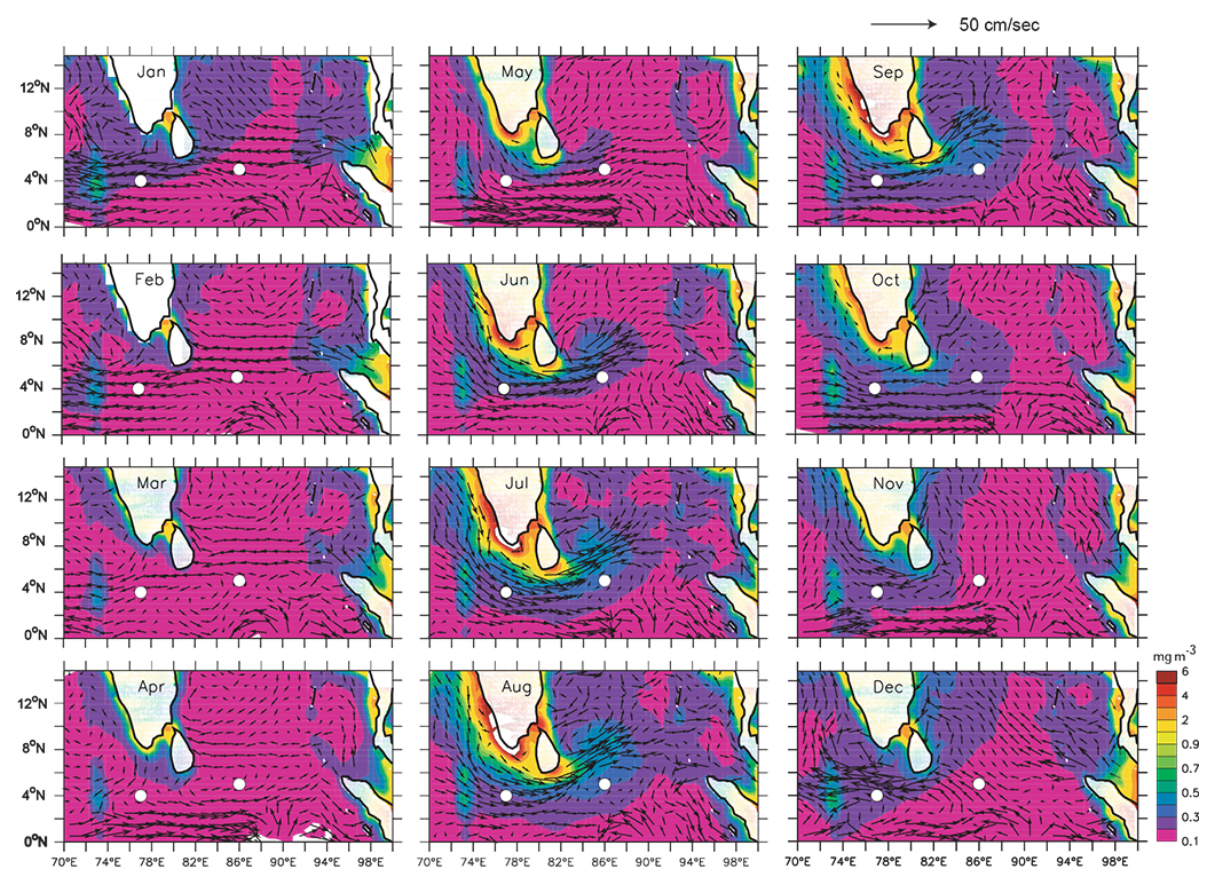

Fig. 10. Monthly mean climatology (1997-2010) of chlorophyll pigment concentration $\left(\mathrm{mg} \mathrm{m}^{-3}\right.$ ) (shading) overlaid with OSCAR current (arrows), white circles represent location of SBBT and EIOT.

$2 \mu \mathrm{M}$ at EIOT. From the vertical profiles of nitrate and silicate, it is obvious that within the MLD the nutrient concentration at SBBT is higher than that of EIOT. Hence, though the extent of wind mixing could be similar in SBBT and EIOT, the nutrient concentration, specifically silicates within the MLD at SBBT were much higher than that at EIOT. This indicated the conditions congenial for the dominance of diatoms (Smetacek, 1998) in the SBBT site. 


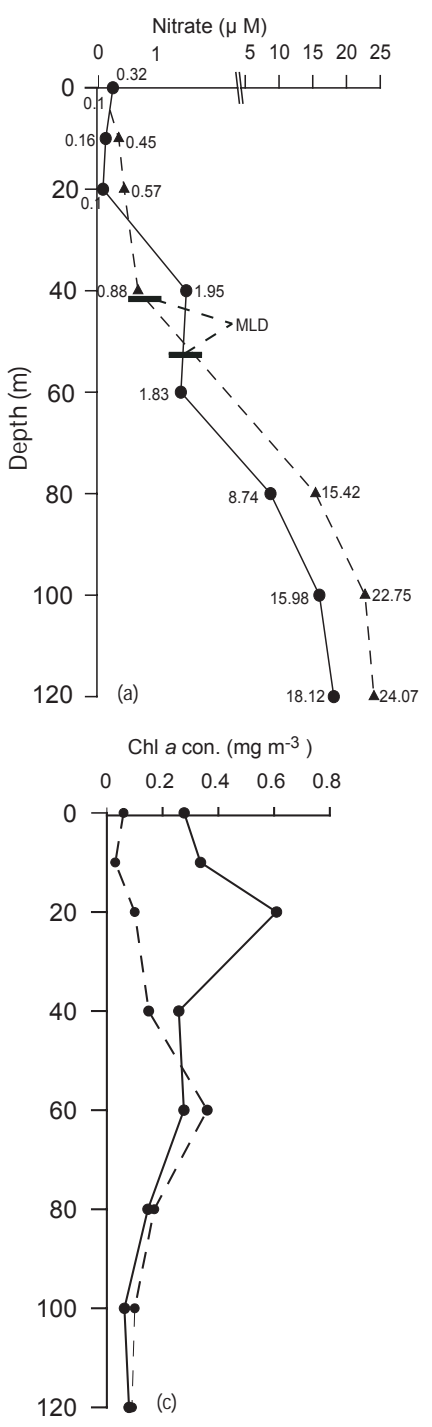

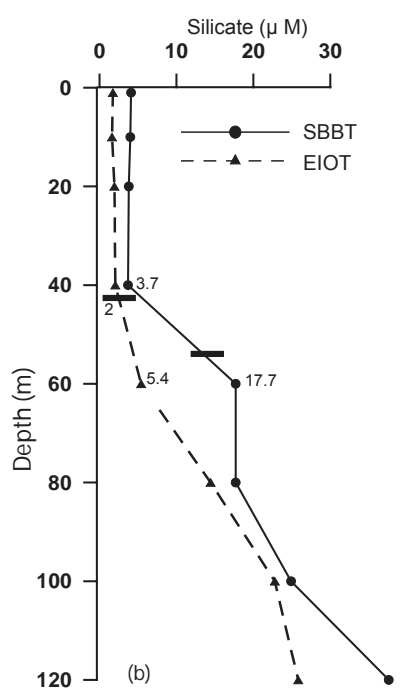

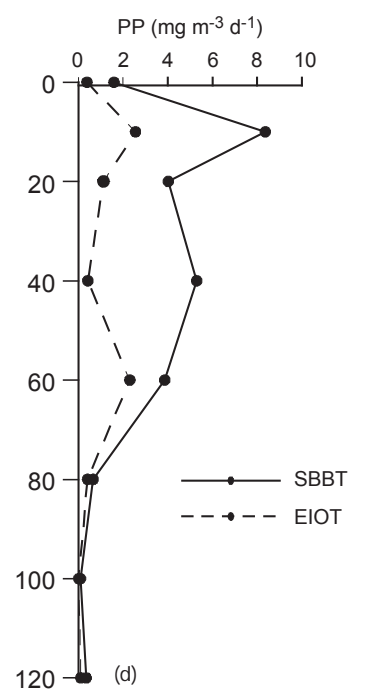

Fig. 11. Vertical profiles of (a) nitrate $(\mu \mathrm{M})$ (b) silicate $(\mu \mathrm{M})$ [Thick black line cutting across the profiles represent the mixed layer depth] (c) chlorophyll $a\left(\mathrm{mg} \mathrm{m}^{-3}\right)$ and (d) primary production $\left(\mathrm{mg} \mathrm{C} \mathrm{m}^{-3}\right)$ in the vicinity of SBBT (solid line) and EIOT (broken line) during August 2006.

To understand the processes that led to the observed lower biogenic flux in the EIOT compared to SBBT we examined the biological parameters.

\subsection{In situ chlorophyll $a$}

The vertical profile of in situ chlorophyll $a(\mathrm{Chl} a)$ in August 2006 showed the presence of a characteristic subsurface chlorophyll maximum (SCM) at both the regions (Fig. 11c). At SBBT, the SCM occurred at $20 \mathrm{~m}$ and had a chlorophyll concentration $\left(0.61 \mathrm{mg} \mathrm{m}^{-3}\right)$ almost twice that of surface $\left(0.36 \mathrm{mg} \mathrm{m}^{-3}\right)$. The SCM contributed $29 \%$ of the total chlorophyll in the upper $120 \mathrm{~m}$ water column whereas the surface biomass contributed only to $14 \%$ of the total. At EIOT the SCM was located at $60 \mathrm{~m}$ depth and had a chlorophyll biomass $\left(0.36 \mathrm{mg} \mathrm{m}^{-3}\right)$ which was six times higher than that of surface concentration $\left(0.06 \mathrm{mg} \mathrm{m}^{-3}\right)$. The SCM contributed $34 \%$ of the total chlorophyll in the upper $120 \mathrm{~m}$ water column at EIOT whereas surface chlorophyll contributed to $6 \%$. Overall, the integrated chlorophyll $a$ concentration in the upper $120 \mathrm{~m}$ at SBBT was much higher $\left(29.6 \mathrm{mg} \mathrm{m}^{-2}\right)$ than that at EIOT $\left(18.7 \mathrm{mg} \mathrm{m}^{-2}\right)$. The major difference in biomass was in the upper $60 \mathrm{~m}$ of the water column.

\subsection{Primary production}

The vertical profiles of primary production (PP) showed much higher PP at SBBT compared to EIOT (Fig. 11d). Surface PP at SBBT $\left(1.59 \mathrm{mg} \mathrm{C} \mathrm{m}^{-3} \mathrm{~d}^{-1}\right)$ was four times higher than that of EIOT $\left(0.38 \mathrm{mg} \mathrm{C} \mathrm{m}^{-3} \mathrm{~d}^{-1}\right)$. The subsurface PPmaximum was seen at $10 \mathrm{~m}$ at SBBT $\left(8.4 \mathrm{mg} \mathrm{C} \mathrm{m}^{-3} \mathrm{~d}^{-1}\right)$. The EIOT showed two maxima - the first one at $10 \mathrm{~m}$ $\left(2.56 \mathrm{mg} \mathrm{C} \mathrm{m}^{-3} \mathrm{~d}^{-1}\right)$ and the second one at $60 \mathrm{~m}-$ which were comparable. The column integrated $(120 \mathrm{~m}) \mathrm{PP}$ values at SBBT $\left(353.6 \mathrm{mg} \mathrm{C} \mathrm{m}^{-2} \mathrm{~d}^{-1}\right)$ were more than three times higher than those at EIOT $\left(108.4 \mathrm{mg} \mathrm{C} \mathrm{m}^{-2} \mathrm{~d}^{-1}\right)$.

\subsection{Phytoplankton abundance and assemblage}

The phytoplankton abundance (Fig. 12a) and composition at SBBT and EIOT was analysed to understand community structure and its spatial variation (Table 1). Numerical abundance showed a subsurface maximum at SBBT which was located at $40 \mathrm{~m}$ with a value of 2576 cells $\mathrm{L}^{-1}$. This was 8-times higher than the maxima at EIOT located at $10 \mathrm{~m}$ and $60 \mathrm{~m}$ with a value of 330 cells $\mathrm{L}^{-1}$ (Fig. 12a). Further, the phytoplankton community was largely dominated by diatoms, which was 8-times higher compared to EIOT (Table 1).

The phytoplankton community (diatom \& dinoflagellates) was also found to be more diverse at SBBT (20 genera) as compared to EIOT (9 genera). The dominant forms at SBBT were Rhizosolenia styliformis (16.9\%), Pseudonitzschia turgidula (9.2\%), Chaetoceros didymus (6\%), Nitzschia delicatissima (5\%) whereas Leptocylindrus danicus (28\%), Synedra spp. (7.8\%), Nitzschia spp. (5.4\%), Thalassiothrix longissima $(4.7 \%)$ dominated EIOT stations. Among dinoflagellates that contributed less than $10 \%$ includes Gymnodinium spp. (3\%) and Prorocentrum micans $(1.9 \%)$ at SBBT while Ceratium trichoceros $(2.7 \%)$ and Phalacroma circumsutum (1.9\%) dominated EIOT.

\subsection{Meso-zooplankton biomass}

The meso-zooplankton biomass in upper $1000 \mathrm{~m}$ was largely dominated by copepods which are 2-fold higher at SBBT $\left(24.47 \mathrm{~mL} \mathrm{~m}^{-3}\right)$ than at EIOT $\left(14.7 \mathrm{~mL} \mathrm{~m}^{-3}\right)$. Vertically, the highest biomass was concentrated in the MLD (0-60 m; 
Table 1. Phytoplankton composition and numerical abundance (cells $\left.\mathrm{L}^{-1}\right)$ at selected stations in the vicinity of $\mathrm{SBBT}\left(5^{\circ} \mathrm{N} ; 83^{\circ} \mathrm{E}\right)$ and EIOT $\left(2.5^{\circ} \mathrm{N} ; 77^{\circ} \mathrm{E}\right)$ during August 2006.

\begin{tabular}{|c|c|c|c|c|c|c|c|c|c|c|c|c|c|c|c|c|}
\hline \multirow{2}{*}{$\begin{array}{l}\text { SK } 227 \text { - 1-30 Aug } 2006 \\
\text { Depths (m) }\end{array}$} & \multicolumn{8}{|c|}{$5^{\circ} \mathrm{N}, 83^{\circ} \mathrm{E}$} & \multicolumn{8}{|c|}{$2.5^{\circ} \mathrm{N}, 77^{\circ} \mathrm{E}$} \\
\hline & 0 & 10 & 20 & 40 & 60 & 80 & 100 & 120 & 0 & 10 & 20 & 40 & 60 & 80 & 100 & 120 \\
\hline \multicolumn{17}{|l|}{ Diatoms (cells L ${ }^{-1}$ ) } \\
\hline Centric & - & - & - & - & - & - & - & - & - & - & - & - & - & - & - & - \\
\hline Biddulphia sp. & - & - & - & - & - & & - & 96 & - & - & - & - & - & - & - & - \\
\hline Chaetoceros danicus & - & - & - & - & - & 160 & - & - & - & - & - & - & - & - & - & - \\
\hline Chaetoceros didymus & - & - & - & 336 & - & 160 & - & - & - & - & - & - & - & - & - & _ \\
\hline Chaetoceros sp. & - & - & 264 & - & - & - & - & - & - & - & - & - & - & - & - & - \\
\hline Coscinodiscus granii & - & - & 88 & - & - & - & - & - & - & - & - & - & - & - & - & - \\
\hline Coscinodiscus perforatus & - & - & & - & - & - & - & - & - & - & - & & 56 & - & - & - \\
\hline Coscinodiscus sp. & - & - & - & - & - & - & - & - & - & - & - & 56 & - & - & - & - \\
\hline Guinardia flaccida & - & - & 88 & - & - & - & - & - & - & - & - & - & - & - & - & - \\
\hline Leptocylindrus danicus & - & - & - & 112 & - & - & - & - & 240 & 96 & - & - & - & 96 & - & - \\
\hline Rhizosolenia curvata & - & - & 88 & - & - & - & - & - & - & - & - & - & - & - & - & - \\
\hline Rhizosolenia imbricata & - & 240 & - & - & - & - & - & - & - & - & - & - & - & - & - & - \\
\hline Rhizosolenia setigera & - & - & - & 336 & - & - & - & - & - & - & - & - & - & - & - & - \\
\hline Rhizosolenia styliformis & 168 & 240 & 88 & 672 & 240 & - & - & - & - & - & - & - & - & - & - & - \\
\hline Pennate & - & - & - & - & - & - & - & - & - & - & - & - & - & - & - & - \\
\hline Amphora sp. & - & & & 224 & & - & - & - & - & - & - & - & - & - & - & - \\
\hline Pseudonitzschuia turgidula & - & - & - & - & - & - & - & 768 & - & - & - & - & - & - & - & - \\
\hline Navicula membranaceae & - & 160 & - & - & - & - & - & - & - & - & - & - & - & - & - & - \\
\hline Navicula sp. & - & - & - & 224 & - & - & - & - & - & - & - & - & - & - & - & - \\
\hline Nitzschia delicatissima & - & - & - & 336 & 80 & - & - & - & - & - & - & - & - & - & - & - \\
\hline Nitzschia longissima & - & - & - & - & 80 & - & - & - & - & - & - & - & - & - & - & - \\
\hline Nitzschia sp. & - & - & - & - & - & - & - & - & - & - & 56 & - & 56 & - & - & _- \\
\hline Synedra sp. & - & - & - & - & - & - & - & - & - & 48 & - & 112 & - & - & - & - \\
\hline Thalassiothrix longissima & - & - & - & - & 80 & - & - & - & - & 96 & - & - & - & - & - & - \\
\hline Dinoflagellates (cells L ${ }^{-1}$ ) & - & - & - & - & - & - & - & - & - & - & - & - & - & - & - & - \\
\hline Alexandrium sp. & - & - & - & - & 80 & - & - & - & - & - & - & - & - & - & - & - \\
\hline Ceratium trichoceros & - & - & - & - & - & - & - & - & - & - & - & 56 & - & - & - & - \\
\hline Ceratium sp. & - & - & - & - & - & - & 84 & - & - & - & - & - & - & - & - & - \\
\hline Gonyaulax sp. & 84 & - & - & - & - & - & - & - & - & - & - & - & - & - & - & - \\
\hline Gymnodinium sp. & - & 160 & - & - & - & - & - & - & - & - & - & - & - & - & - & - \\
\hline Ornithoceros sp. & - & - & - & 112 & - & - & - & - & - & - & - & - & - & - & - & - \\
\hline Phalacroma circumsutum & - & - & - & - & - & - & - & - & 40 & - & - & - & - & - & - & - \\
\hline |Peridinium sp. & - & - & 88 & - & - & - & - & - & - & - & - & - & - & - & - & - \\
\hline Polykrikos sp. & - & - & - & - & 80 & - & - & - & - & - & - & - & - & - & - & - \\
\hline Prorocentrum micans & - & - & - & - & 160 & - & - & - & - & - & - & - & - & - & - & _- \\
\hline Prorocentrum sp. & - & 80 & - & - & - & - & - & - & - & - & - & - & - & - & - & - \\
\hline Protoperidinium sp. & - & - & - & - & 80 & - & - & - & - & - & - & - & - & - & - & - \\
\hline Pyrophacus sp. & - & - & - & - & 80 & - & - & - & - & - & - & 56 & - & - & - & - \\
\hline Dinoflagellate cyst & - & - & - & - & - & - & - & - & - & 96 & - & - & 224 & - & 128 & 256 \\
\hline Unidentified Phytoplanktons & & 80 & & 224 & 80 & & 1176 & & & & & & & & & \\
\hline Total (cells L $\left.{ }^{-1}\right)$ & 252 & 960 & 704 & 2576 & 1040 & 320 & 1260 & 864 & 280 & 336 & 56 & 280 & 336 & 96 & 128 & 256 \\
\hline
\end{tabular}

Fig. 12b). In the upper $300 \mathrm{~m}$ also the meso-zooplankton biomass at EIOT was lower than that at SBBT.

\subsection{Micro-zooplankton}

The micro-zooplankton was largely comprised of Protozoans, particularly ciliates and flagellates. We considered micro-zooplankton abundance along with meso-zooplankton biomass to have a basic understanding about the kind of food web that might be functional in SBBT and EIOT. Spatial variation in micro-zooplankton abundance along $77^{\circ} \mathrm{E}$ (EIOT) and $83^{\circ} \mathrm{E}$ (SBBT) showed high micro-zooplankton abun- dance at EIOT (1000 Organisms $\mathrm{L}^{-1}$ ) compared to SBBT (500-600 Organisms L ${ }^{-1}$ ) (Fig. 12c).

\subsection{Size fractionated chlorophyll $a$}

Size fractionated chlorophyll $a$ along $77^{\circ} \mathrm{E}\left(5^{\circ} \mathrm{N}\right.$ and at Equator) as shown in Fig. 13, which indicate that the picophytoplanktons $(<10 \mu \mathrm{m}$ but $>0.7 \mu \mathrm{m})$ dominated the phytoplankton biomass at all the depths (Fig. 13). At selected depths (surface, SCM, and $120 \mathrm{~m}$ ) pico-phytoplankton accounted for $79 \%, 94 \%, 66 \%$ at $5^{\circ} \mathrm{N}$ and $93 \%, 94 \%$, and $70 \%$ at the equator respectively. 

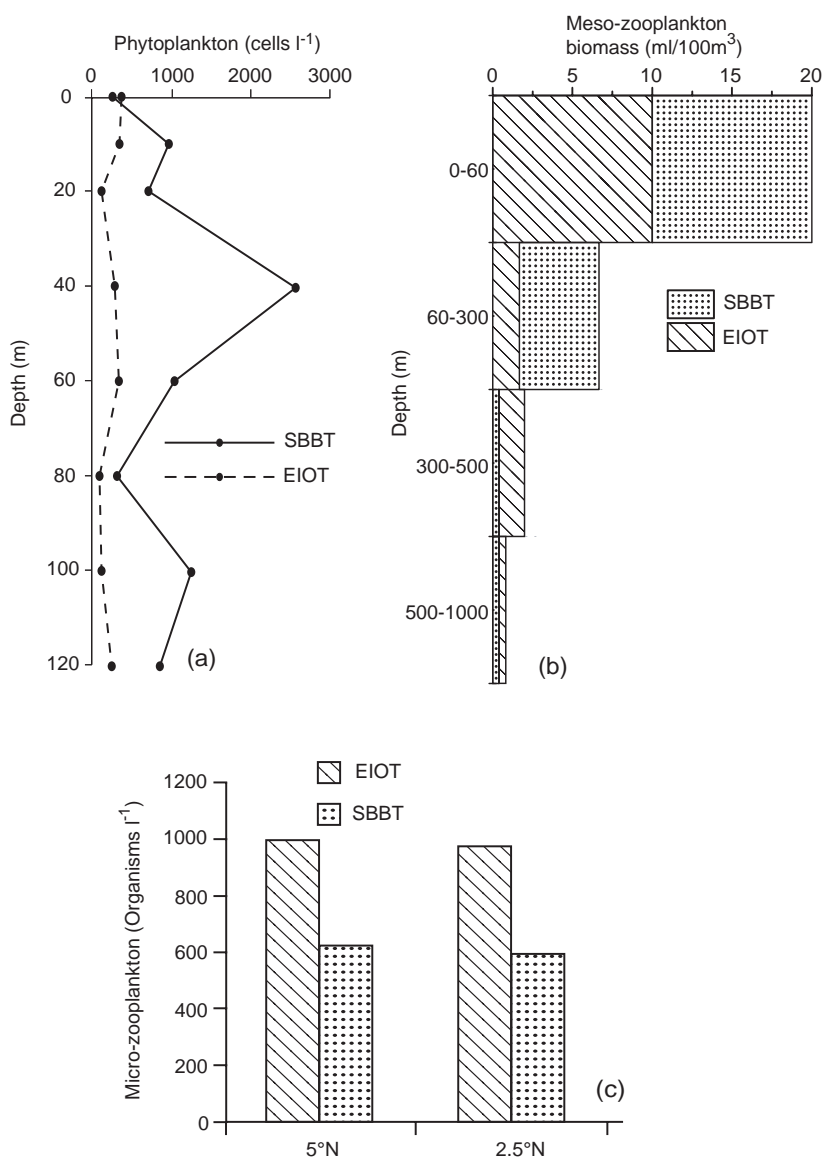

Fig. 12. Vertical profiles of (a) phytoplankton abundance (cells $\mathrm{L}^{-1}$ ) in the vicinity of SBBT (solid line) and EIOT (broken line) (b) vertically stratified meso-zooplankton biomass in the vicinity of SBBT (dots) and EIOT (hatches) and (c) Micro-zooplankton (organisms $\mathrm{L}^{-1}$ ) at selected stations along SBBT (dots) and EIOT (hatches) during August 2006.

\section{Discussion}

The characteristic feature of the mid-depth biogenic flux at SBBT was strong seasonality with peak flux during summer monsoon (June-September), which was observed regularly over the period 1988-1997 (Unger et al., 2006). In contrast, EIOT showed a consistently low flux without any seasonality, the flux being two-and-a-half times less than that of SBBT. The observed differential biogenic flux at SBBT and EIOT could be understood in the context of prevailing physical as well as biological processes at these locations both of which influence the chlorophyll biomass. At any given location chlorophyll biomass depends on the availability of sunlight and nutrients (bottom-up control) and grazing (topdown control). The bottom-up control in turn depends up on the physical processes. We first examined the physical process to understand the observed variability in the chlorophyll biomass and then the processes that control the biogenic flux to the deeper ocean.

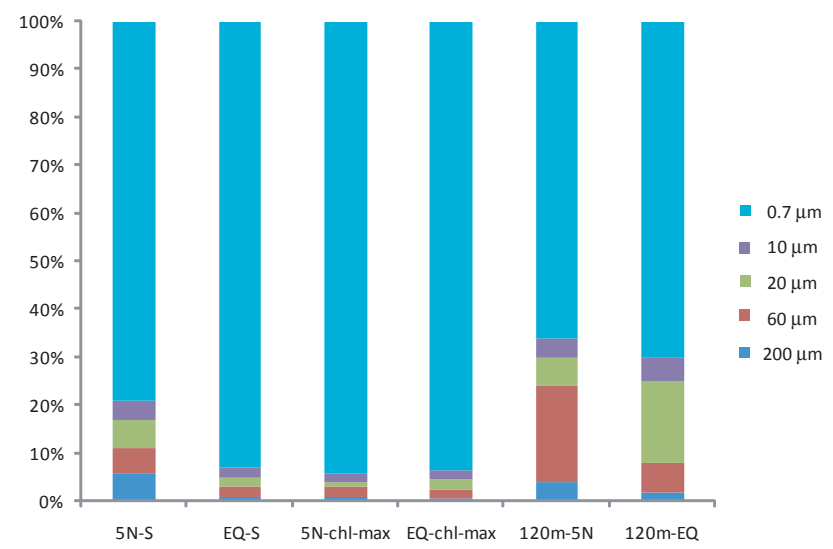

Fig. 13. Size fractionated phytoplankton biomass ( $\left.\mathrm{mg} \mathrm{Chl} a \mathrm{~m}^{-3}\right)$ in percentage during August 2006 at $5^{\circ} \mathrm{N}$ and equator along $77^{\circ} \mathrm{E}$ from surface, chlorophyll maximum and at $120 \mathrm{~m}$.

The time evolution of satellite derived chlorophyll, showed a distinct seasonality at both SBBT and EIOT. Though the peak chlorophyll occurred during summer monsoon at both the locations, the magnitude at SBBT was marginally higher than that at EIOT. The in situ measurements of surface chlorophyll $a$ in August 2006 also showed a similar result. The column integrated chlorophyll $a$ as well as PP was also higher by one-and-a-half times at SBBT compared to EIOT. An examination of PAR showed only a marginal difference between the two locations. Though wind speeds at SBBT during summer monsoon was higher than that at EIOT, it did not result in a significant difference in the MLD between them as the static stability at both the locations were comparable. However, higher concentration of silicate and nitrate within the MLD at SBBT compared to EIOT could potentially enhance the chlorophyll biomass at SBBT even when the magnitude of the wind mixing is comparable at these locations. Another mechanism that could contribute to the chlorophyll enhancement at SBBT was advection from south of Sri Lanka, a region of high chlorophyll driven by Ekman-pumping, by the southwest monsoon current (SMC), which passes through the trap site. Thus, at SBBT combined effect of wind-mixing and horizontal advection contributed to the high chlorophyll during summer monsoon, while at EIOT wind-mixing alone led to the moderate enhancement of chlorophyll. Though bottom-up control could explain the observed differential enhancement of chlorophyll biomass between SBBT and EIOT during summer monsoon, it fails to explain the mid-depth biogenic flux variability between them.

In the light of the inadequacy of the bottom-up control to explain the mismatch between the chlorophyll biomass and biogenic flux during summer monsoon, we examined the longitudinal differences in the prevailing plankton community and the associated biological processes that operate at these locations. Buesseler (1998) reported a decoupling 
between primary production and export of organic carbon to the deeper part of the water column, and found that high export rates were mostly related to diatom based food webs. Against this background we used available in situ data of nitrate, chlorophyll $a$, PP, phytoplankton cell number, mesozooplankton biomass and micro-zooplankton that were collected near SBBT and EIOT during August 2006 as a part of the Equatorial Indian Ocean Process Study (EIOPS) programme (Prasanna Kumar et al., 2010) to evaluate food web structure of the respective sites. Our results based on microscopic as well as size fractionated chlorophyll $a$ studies showed that the cell count of the larger $(>5 \mu \mathrm{m})$ phytoplankton was dominated by diatoms at SBBT and was several times higher than that compared to EIOT. We presume that the higher cell count of larger phytoplankton at SBBT was supported by the higher concentration of new nitrogen made available by strong wind-mixing and horizontal advection. The meso-zooplankton biomass at SBBT in the upper $300 \mathrm{~m}$ was more than twice that at EIOT, while the microzooplankton at SBBT was one-and-half times less than that at EIOT. Thus, the dominance of diatom and meso-zooplankton over micro-zooplankton at SBBT suggested the prevalence of classical food web. The resulting export could be both via aggregation following a diatom bloom and through fecal pellets due to meso-zooplankton grazing.

In contrast, at EIOT the peaks of both primary production and chlorophyll $a$ (SCM) occurred at $60 \mathrm{~m}$ which was located in the low light region, a condition congenial for the prevalence of pico-phytoplankton (see Glover et al., 1985; Platt et al., 1983). Our size fractionated chlorophyll $a$ also showed that the enhanced phytoplankton biomass at EIO was dominated by pico-phytoplankton. The high micro-zooplankton abundance and lower meso-zooplankton biomass at EIOT indicated the importance of the microbial loop. This food web is believed to be more efficient at re-cycling (Beatriz et al., 2001) and is generally associated with low export.

The above difference in fluxes is also reflected in the phytoplankton community structure, which was more diverse near SBBT (20 genera) as compared to that near EIOT (9 genera) wherein, large standing stock of pico-autotrophs were expected to be consumed by protozoa (ciliates, flagellates), dominant forms of micro-zooplankton (Madhupratap et al., 1996; Gauns et al., 2005). This is also reflected in the comparatively higher opal fluxes at SBBT site. Further, foraminifera are part of the microplankton taxa, suggesting their importance (possibly through grazing) in the microbial components of the region. Thus, at EIOT most of the photosynthetically produced organic matter is remineralized within the upper ocean leaving very little carbon to sink (Banse, 2013; Boyd and Trull, 2007, Williams, 1998). Finally, we present a schematic picture (Fig. 14), that depicts the above discussed physical-biological processes starting from organic carbon production in the euphotic zone, its transformation and transportation to mesopelagic zone as captured by the sediment trap at SBBT and EIOT located

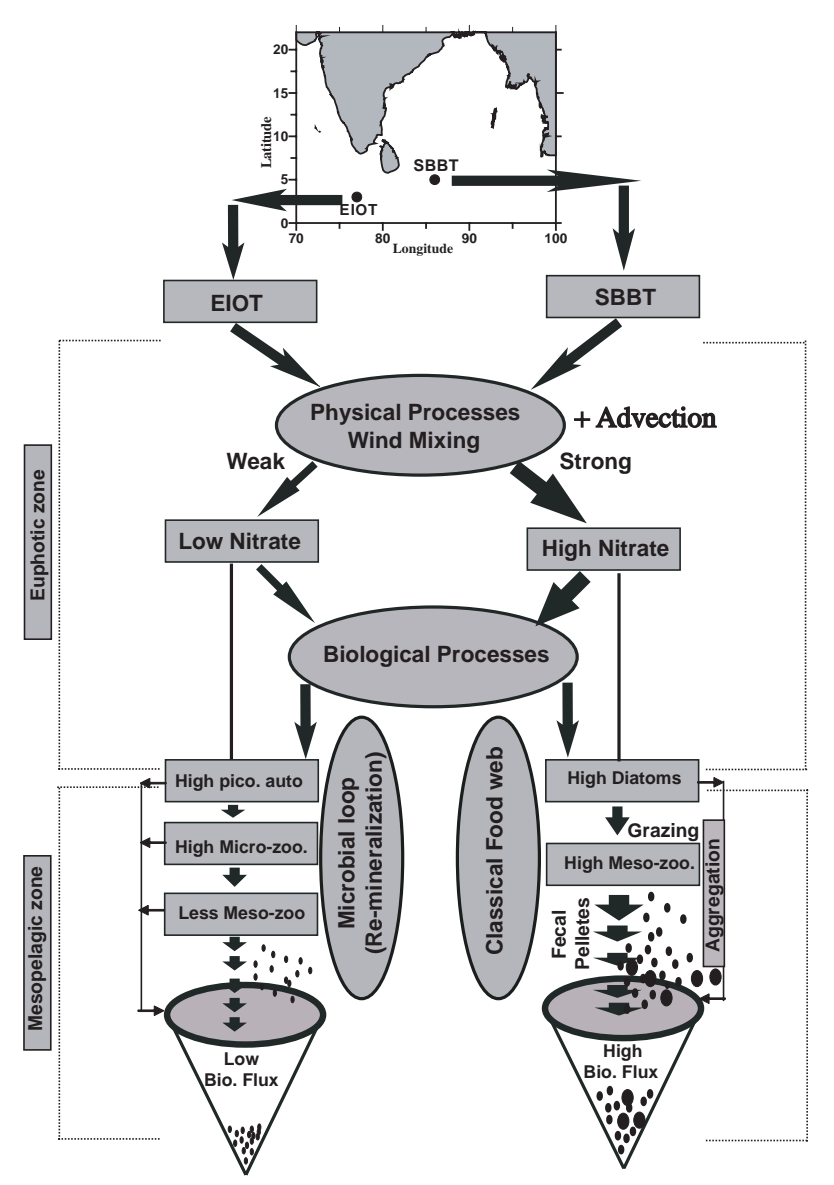

Fig. 14. Schematic picture summarising the physical and biological processes starting from production of organic carbon in the upper ocean to its export into the deep ocean as captured by the sediment trap at SBBT and EIOT (see text for details).

within the same geographical region. At EIOT, the weak wind mixing and the associated low nitrate levels lead to the observed low chlorophyll biomass. This low chlorophyll biomass and high micro-zooplankton biomass suggests the operation of microbial loop which re-mineralizes most of the photosynthetically produced organic matter within the upper ocean. In contrast, at SBBT the higher wind mixing and advection supplies new nitrate as well as silicate to the euphotic zone to support diatom growth via classical food web. The high diatom along with high meso-zooplankton biomass contributed to the export of carbon via both aggregation of faster sinking diatoms and fecal pellets.

\section{Concluding remarks}

Sediment trap data from the equatorial Indian Ocean region provided valuable insight into the processes that link the primary production to the sinking organic carbon in which physical and biological processes are intimately coupled. Our 
study demonstrates that, though SBBT and EIOT are within the same geographical entity, the processes that control the primary production in the euphotic zone and the biogenic flux to the deep ocean are very different. To the best of our knowledge this is the first such attempt in the EIO. There are some uncertainties in our study, especially the role of mesozooplankton grazing, which needs to be quantified. We also would need data on dissolved organic carbon to have a better handle on the microbial food web.

Acknowledgements. The authors thank the Director CSIR-NIO Goa and Council of Scientific and Industrial Research (CSIR), New Delhi for all support and encouragement. They express their gratitude to R. Antao (retired), Department of English, Dhempe College of Arts and Science, Panaji, Goa for meticulously going through the manuscript and suggesting language corrections. This paper benefitted immensely from the comments and suggestions of the two anonymous reviewers as well as from the review of K. Banse. We wish to thank them. All the participants of ORV Sagar Kanya cruise 227 are acknowledged for their help in data collection and analysis. P. J. Vidya acknowledges CSIR for Senior Research Fellowship. This is NIO contribution number 5482.

Edited by: C. Robinson

\section{References}

Balmaseda, M. A., Vidard, A., and Anderson, D. L. T.: The ECMWF Ocean Analysis System: ORA-S3, Mon. Weather Rev., 136, 3018-3034, 2008.

Banse, K.: Reflections about chance in my career, and on the Topdown regulated world, Annu. Rev. Mar. Sci., 5, 1-19, 2013.

Beatriz, M. B., Fasham, M. J. R., and Bowles, M. C.: Ocean biogeochemistry and Global Change: JGOFS Research Highlights 1988-2000, SCOR, IGBP, National Science Foundation, Research Council of Norway, University of Bergen, IGBP Science Series 2, 36 pp., 2001.

Betzer, P. R., Showers, W. J., Laws, E. A., Winn, C. D., DiTullio, G. R., and Kroopnick, P. M.: Primary productivity and particle fluxes on a transect of the equator at $153^{\circ} \mathrm{W}$ in the Pacific Ocean, Deep-Sea Res., 31, 1-11, 1984.

Bishop, J. K. B.: Regional extremes in particulate matter composition and flux: effects on the chemistry of the ocean interior, in: Productivity of the ocean: Present and past, edited by: Berger, W. H., Smetacek, V. S., and Wefer, G., J. Wiley and Sons, Chichester, UK, 117-137, 1989.

Bonjean, F. and Lagerloef, G. S. E.: Diagnostic model and analysis of the surface currents in the tropical Pacific ocean, J. Phys. Oceanogr., 32, 2938-2954, 2002.

Boyd, P. W. and Trull, T. W.: Understanding the export of biogenic particles in oceanic waters: Is there consensus?, Prog. Oceanogr., 72, 276-312, doi:10.1016/j.pocean.2006.10.007, 2007.

Bradtmiller, L. I., Anderson, R. F., Fleisher, M. Q., and Burckle, L. H.: Opal burial in the equatorial Atlantic Ocean over the last $30 \mathrm{ka}$ : Implications for glacial- interglacial changes in the ocean silicon cycle, Paleoceanography, 22, PA4216, doi:10.1029/2007PA001443, 2007.
Bubnov, V. A.: Climatic zonal pressure gradient in the equatorial zone of the Indian Ocean, Oceanology, 33, 414-420, 1994.

Buesseler, K. O.: The decoupling of production and particulate export in the surface ocean, Global Biogeochem. Cy., 12, 297-310, 1998.

Buesseler, K. O., Antia, A. N., Chen, M., Fowler, S. W., Gardner, W. D., Gustafsson, O., Harada, K., Michaels, A. F., Rutgers van der Loeff, M., Sarin, M., Steinberg, D. K., and Trull, T.: An assessment of the use of sediment traps for estimating upper ocean particle fluxes, J. Mar. Res., 65, 345-416, 2007.

Carr, M.-E., Friedrichs, M. A. M., Schmeltz, M., Aita, M. N., Antoine, D., Arrigo, K. R., Asanuma, I., Aumont, O., Barber, R., Behrenfeld, M., Bidigare, R., Buitenhuis, E. T., Cambell, J., Ciotti, A., Dierssen, H., Dowell, M., Dunne, J., Esaias, W., Gentili, B., Gregg, W., Groom, S., Hoepffner, N., Ishizaka, J., Kameda, T., LeQuéré, C., Lohrenz, S., Marra, J., Mélin, F., Moore, K., Morel, A., Reddy, T. E., J. Ryan, M. Scardi, Smyth, T., Turpie, K Tilstone, G., Waters, K., and Yamanaka, Y.: A comparison of global estimates of marine primary production from ocean color, Deep-Sea Res. II, 533, 741770 doi:10.1016/j.dsr2.2006.01.028, 2006.

Clarke, A. J. and Liu, X.: Observations and dynamics of semiannual and annual sea levels, J. Phys. Oceanogr., 23, 386-399, 1993.

Fernandes, V., Rodrigues, V., Ramaiah, N., and Paul, J. T.: Relevance of bacterioplankton abundance and production in the oligotrophic equatorial Indian Ocean, Aquat. Ecol., 42, 511-519, 2008.

Fischer, G., Fütterer, D., Gersonde, R., Honjo, S., Ostermann, D., and Wefer, G.: Seasonal variability of particle flux in the Weddell Sea and its relation to ice cover, Nature, 335, 426-428, 1988.

Frouin, R. and Murakami, H.: Estimating Photosynthetically Available Radiation at the Ocean surface from ADEOS-11 Global Imager data, J. Oceanogr., 63, 493-503, 2007.

Gauns, M., Madhupratap, M., Ramaiah, N., Jyothibabu, R., Fernandes, F., Paul, J., and Prasanna Kumar, S.: A comparative account of biological productivity characteristics and estimates of carbon fluxes in the Arabian Sea and Bay of Bengal, Deep Sea Res. II , 52, 2003-2017, 2005.

Gill, A. E.: Atmosphere-Ocean Dynamics, Academic Press, London, UK, 662 pp., 1982.

Gonella, J., Reverdin, G., and Fieux, M.: Dynamical Oceanographyhypothesis in favour of the genesis of the equatorial oceanic jet of the Indian Ocean by attenuation of the Somalian eddy after the end of the south-west monsoon, Compt. Rend. Acad. Sci. Paris, 29, 899-902, 1983.

Glover, H. E., Phinney, D. A., and Yentsch, C. S.: Photosynthetic characteristics of picoplankton compared with those of larger phytoplankton populations, in various water masses in the Gulf of Maine, Biol. Oceanogr., 3, 223-248, 1985.

Hakke, B., Rixen, T., Reemtsma, T., Ramaswamy, V., and Ittellot, V.: Processes determining seasonality and interannual variability of settling particle fluxes to the deep Arabian Sea, in: Particle Flux in the Ocean, edited by: Ittekkot, V., Honjo, S., and Depetris, P. J., 251-270, John wiley, Chichester, UK, 1996.

Hastenrath, S. and Greischar, L.: The monsoonal heat budget of the hydrosphere-atmosphere system in the Indian Ocean sector, J. Geophys Res., 98, 6869-6881, 1989.

Helmke, P., Neuer, S., Lomas, M. W., Conte, M., and Freudenthal, T.: Cross-basin differences in particulate organic carbon export 
and flux attenuation in the subtropical North Atlantic gyre, Deep Sea Res. I, 57, 213-227, 2010.

Holmes, R. M., McClelland, J. W., Peterson, B. J., Shiklomanov, I. A., Shiklomanov, A. I., Zhulidov, A. V., Gordeev, V. V., and Bobrovitskaya, N. N.: A circumpolar perspective on fluvial sediment flux to the Arctic Ocean, Global Biogeochem. Cy., 16, 1098, doi:10.1029/2001GB001849, 2002.

Honjo, S.: Seasonality and interaction of biogenic and lithogenic particulate flux at the Panama Basin, Science, 218, 883-884, 1982.

Honjo, S., Dymond, J., Prell, W., and Ittekkot, V.: Monsooncontrolled export fluxes to the interior of the Arabian Sea, Deep Sea Res. II, 46, 1859-1902, 1999.

Ittekkot, V.: The abiotically driven biological pump in the ocean and short-term fluctuations in atmospheric $\mathrm{CO}_{2}$ contents, Global Planet. Change., 8, 17-25, 1993.

Jickells, T. D., Newton, P. P., King, P., Lampitt, R. S., and Boutle, C.: A comparison of sediment trap records of particle fluxes from 19 to $48 \hat{\mathrm{A}}^{\circ} \mathrm{N}$ in the northeast Atlantic and their relation to surface water productivity, Deep Sea Res. I, 43, 971-986, 1996.

Knauss, J. A.: Measurements of the Cromwell Current, Deep-Sea Res., 6, 265-286, 1960.

Knox, R. A.: On a long series of the Indian Ocean equatorial currents near Addu Atoll, Deep-Sea Res., 23, 211-221, 1976.

Koné, V., Aumont, A., Lévy, M., and Resplandy, L.: Physical and biogeochemical controls of the phytoplankton seasonal cycle in the Indian Ocean: A modeling study, Geoph. Monog. Series, 185, 147-166, doi:10.1029/2008GM000700, 2009.

le B. Williams, P. J.: The balance of plankton respiration and photosynthesis in the open ocean, Nature, 394, 55-57, 1998.

Lebour, M.: The Planktonic Diatom of Northern Seas, Otto Koeltz Science Publishers, 6240 Koenigstein, W-Germany, 25-215, 1978.

Leetma, A. and Stommel, H.: Equatorial current observations in the western Indian Ocean in 1975 and 1976, J. Phys. Oceanogr., 10, 258-269, 1980

Lévy, M., Shankar, D., André, J. M., Shenoi, S. S. C., Durand, F., and de Boyer Montégut, C.: Basin-wide seasonal evolution of the Indian Ocean's phytoplankton blooms, J. Geophys. Res., 112, C12014, doi:10.1029/2007JC004090, 2007.

Longhurst, A.: Seasonal cycles of pelagic production and consumption, Prog. Oceanogr., 36, 77-167, 1995.

Lutz, M., Dunbar, R., and Caldiera, K.: Regional variability in the vertical flux of articulate organic carbon in the ocean interior, Global Biogeochem. Cy., 16, 1037, doi:10.1029/2000GB001383, 2002.

Lutz, V. A., Segura, V., Dogliotti, A. I., Gagliardini, D. A., Bianchi, A. A., and Balestrini, C. E.: Primary production in the Argentine Sea during spring estimated by field and satellite models, J. Plankton Res., 32, 181-195, 2010.

Luyten, J. R. and Roemmich, D. H.: Equatorial currents at semiannual period in the Indian Ocean, J. Phys. Oceanogr., 12, 406-413, 1982.

Madhupratap, M., Prasanna Kumar, S., Bhattathiri, P. M. A., Dileep Kumar, M., Raghukumar, S., Nair, K. K. C., and Ramaiah, N.: Mechanism of the biological response to winter cooling in the northeastern Arabian Sea, Nature, 384, 549-552, 1996.

Madhupratap, M., Gopalakrishnan, T. C., Haridas, P., and Nair, K. K. C.: Mesozooplankton biomass, composition and distribution in the Arabian Sea during the fall intermonsoon: Implications of oxygen gradients, Deep-Sea Res. II, 48, 1345-1368, 2001.

Masumoto, Y., Hase, H., Kuroda, Y., Matsuura, H., and Takeuchi, $\mathrm{K}$.: Intraseasonal variability in the upper layer currents observed in the eastern equatorial Indian Ocean, Geophys. Res. Lett., 32, L02607, doi:10.1029/2004GL021896, 2005.

McCreary, J. P., Murtugudde, R., Vialard, J., Vinayachandran, P. N., Wiggert, J. D., Hood, R. R., Shankar, D., and Shetye, S. R.: Biophysical Processes in the Indian Ocean, Geoph. Monog. Series, 185, 9-32, doi:10.1029/2008GM000768, 2009.

Murray, J. W., Barber, R. T., Roman, M. R., Bacon, M. P., and Feely, R. A.: Physical and biological controls on carbon cycling in the equatorial Pacific, Science, 266, 58-65,1994.

Narvekar, J. and Prasanna Kumar, S.: Upper ocean variability of the equatorial Indian Ocean and its relation to chlorophyll pigment concentration, in: Proceedings of OceanObs'09: Sustained Ocean Observations and Information for Society (Annex), Venice, Italy, 21-25 September 2009, edited by: Hall, J., Harrison, D. E. and Stammer, D., ESA Publication, doi:10.5270, 2010.

Platt, T., Subba Rao, D. V., and Irwin, B.: Photosynthesis of picoplankton in the oligotrophic Ocean, Nature, 301, 702-704, 1983.

Pond, S. and Pickard, G. L.: Introductory Dynamical Oceanography, second ed. Pergamon, New York, 379 pp., 1983.

Prasanna Kumar, S., Sardesai, S., and Ramaiah, N.: A decade of physical and biogeochemical measurements in the northern Indian ocean, in roceedings of OceanObs'09: Sustained Ocean Observations and Information for Society (Annex), Venice, Italy, 21-25 September 2009, edited by: Hall, J., Harrison, D. E., and Stammer, D., ESA Publication, doi:10.5270, 2010.

Prasanna Kumar, S., David, D. T., Byju, P., Narvekar, J., Yoneyama, K., Nakatani, N., Ishida, A., Horii, T., Masumoto, Y., and Mizuno, K.: Bio-physical coupling and ocean dynamics in the central equatorial Indian Ocean during 2006 Indian Ocean Dipole, Geophys. Res. Lett., 39, L14601, doi:10.1029/2012GL052609, 2012.

Ramaswamy, V. and Gaye, B.: Regional variations in the fluxes of foraminifera carbonate, coccolithophorid carbonate and biogenic opal in the northern Indian Ocean, Deep Sea Res. I, 53, 271-293, 2006.

Rao, R. R., Girish Kumar, M. S., Ravichandran, M., Rao A. R., Gopalakrishna, V. V., and Thadathil, P.: Interannual variability of Kelvin wave propagation in the wave guides of the equatorial Indian Ocean, the coastal Bay of Bengal and the Southeastern Arabian Sea during 1993-2006, Deep Sea Res. I, 57, 1-13, 2010.

Rayner, N. A., Parker, D. E., Horton, E. B., Folland, C. K., Alexander, L. V., Rowell, D. P., Kent, E. C., and Kaplan, A.: Global analyses of sea surface temperature, sea ice, and night marine air temperature since the late nineteenth century, J. Geophys. Res., 108, 4407, doi:10.1029/2002JD002670, 2003.

Reppin, J., Schott, F. A., Fisher, J., and Quadfasel, D.: Equatorial currents and transports in the upper central Indian Ocean: Annual cycle and internal variability, J. Geophys Res., 104, 1549515514, 1999.

Reverdin, G.: The upper equatorial Indian Ocean: the multi-year averaged seasonal cycle, J. Phys. Oceanogr., 17, 903-927, 1987.

Reverdin, G. and Luyten, J.: Near-surface meanders in the equatorial Indian Ocean, J. Phys. Oceanogr., 16, 1088-1100, 1986. 
Rixen, T., Ittekkot, V., Herunadi, B., Wetzel, P., MaierReimer, E., and Gaye-Hakke, B.: ENSO-driven carbon sea saw in the Indo-Pacific, Geophys. Res. Lett., 33, L07606, doi:10.1029/2005GL024965, 2006.

Rixen, T., Ramaswamy, V., Gaye, G., Herunadi, B., Maier-Reimer, E., Bange, H. W., and Ittekkot, V.: Monsoonal and ENSO Impacts on Particle Fluxes and the Biological Pump in the Indian Ocean, Indian Ocean Biogeochemical Processes and Ecological Variability, Geoph. Monog. Series, 185, American Geophysical Union, doi:10.1029/2008GM000706, 2009.

Schott, F. and McCreary, J. P.: The monsoon circulation of the Indian Ocean, Prog. Oceanogr., 51, 1-123, 2001.

Schott, F., Dengler, M., and Schoenefeldt, R.: The shallow thermohaline circulation of the Indian Ocean, Prog. Oceanogr., 53, 57103, 2002.

Shankar, D., Vinayachandran, P. N., and Unnikrishnan, A. S.: The monsoon currents in the north Indian Ocean, Prog. Oceanogr., 52, 63-120, 2002.

Shetye, S. R. and Gouveia, A. D.: Coastal circulation in the north Indian Ocean, edited by: Robinson, A. R. and Brink, K. H., The Sea John Wiley \& Sons, Inc., New York, 11, 523-556, 1998.

Siegel, D. A. and Deuser, W. G.: Trajectories of sinking particles in the Sargasso Sea: modeling of statistical funnels above deep-ocean sediment traps, Deep Sea Res. I, 44, 1519-1541, doi:10.1016/S0967-0637(97)00028-9, 1997.

Siegel, D. A. and Franz, B. A.: Century of phytoplankton change, Nature, 466, 569-571, 2010.

Siegel, D. A., Iturriaga, R., Bidigare, R. R., Pak, H., Smith, R. C., Dickey, T. D., Marra, J., and Baker, K. S.: Meridional variations of the springtime phytoplankton community in the Sargasso Sea, J. Mar. Res., 48, 379-412, 1990.

Siegel, D. A., Fields, E., and Buesseler, K. O.: A bottomup view of the biological pump: Modeling source funnels above ocean sediment traps, Deep-Sea Res. I, 55, 108-127, doi:10.1016/j.dsr.2007.10.006, 2008.

Smetacek, V.: Biological oceanography: Diatoms and the silicate factor, Nature, 391, 224-225, 1998.

Stalcup, M. C. and Metcalf, W. G.: Direct measurements of the Atlantic equatorial undercurrent, J. Mar. Res., 24, 44-45, 1966.

Subrahmanyan, R.: A systematic account of the marine plankton diatoms of the Madras coast, Proc. India. Acad. Sci. B, 24, 85$197,1946$.
Tomas Carmelo, R.: Identifying Marine Phytoplankton, Academic, United Kingdom, 29-549, 1997.

Tsai, P. T. H., O'Brien, J. J., and Luther, M. E.: The 26-day oscillation observed in the Satellite Sea surface temperature measurements in the equatorial western Indian Ocean, J. Geophys. Res., 97, 9605-9618, 1992.

UNESCO: Protocols for the Joint Global Ocean Flux Study (JGOFS), Manual and Guide, 97-128, 1994.

Unger, D., Ittekkot, V., Schafer, P., Tiemann, J., and Reschke, S.: Seasonality and interannual variability of particle fluxes to the deep Bay of Bengal: Influence of reverine input and oceanographic processes, Deep-Sea Res. II, 50, 897-923, 2003.

Unger, D., Schäfer, P., Ittekkot, V., and Gaye, B.: Nitrogen isotopic composition of sinking particles from the southern Bay of Bengal: Evidence for variable nitrogen sources, Deep-Sea Res. I, 53, 1658-1676, 2006.

Voss, R. and Sausen, R.: Techniques for asynchronous and periodically synchronous coupling of atmosphere and ocean models, Part II: impact of variability, Clim. Dynam., 12, 605-614, 1996.

Waniek, J. J., Schulz-Bull, D. E., Blanz, T., Prien, R. D., Oschlies, A., and Muller, T. J.: Interannual variability of deep water particle flux in relation to production and lateral sources in the northeast Atlantic, Deep-Sea Res. I, 52, 33-50, 2005.

Wefer, G. and Fischer, G.: Seasonal pattern of vertical particle flux in the equatorial and coastal upwelling areas of the eastern Atlantic, Deep-Sea Res, I, 40, 1613-1645, 1993.

Wiggert, J. D., Murtugudde, R. G., and Christian, J. R.: Annual ecosystem variability in the tropical Indian Ocean: Results of a coupled bio-physical ocean general circulation model, Deep-Sea Res. II, 53, 644-676, 2006.

Wiggert, J. D., Vialard, J., and Behrenfeld, M. J.: Basinwide modification of dynamical and biogeochemical processes by the positive phase of the Indian Ocean dipole during the SeaWiFS era, Geoph. Monog. Series, 185, 385-407, doi:10.1029/2008GM000776, 2009.

Wyrtki, K.: An equatorial jet in the Indian Ocean, Science, 181, 262-264, 1973. 